\title{
From Sunset Winter to Caetano’s Spring: The Importance of a Song Contest in the Portuguese Music Scene of the 1960’s and 1970’s
}

\author{
Sofia Isabel Fonseca Vieira Lopes \\ Universidade Nova de Lisboa, Lisbon, Portugal
}

\begin{abstract}
I propose to introduce a few lines of analysis for the RTP Song Contest (Portuguese Radio and Television Song Contest—Festival RTP da Canção). I intend to raise a few questions that will help us to understand the role of this competition in the Portuguese musical and cultural scene of the 1960s. RTP Song Contest is the longest television song contest in Portugal. This competition went through several crucial moments in the recent history of Portugal, witnessing the change from dictatorship to democracy. In late 1960s, still under the authoritarian regime, several social changes took place and music played an important role in these changes, as several studies have documented. In 1969, Portugal bet on Simone de Oliveira to bring us the prize, but the result was not the expected. This event brought us many questions about the importance of the Portuguese participation in the Eurovision Song Contest and the fairness of the European evaluation. This paper intends to reflect the implications of this particular event and the importance of the Contest for the Portuguese music scene at the end of the critical 1960's. With this paper, I intend to introduce some lines of analysis of the first ten years of the Portuguese Radio and Television Song Contest (Festival RTP da Canção-RTP Song Contest). I intend to raise a few questions that will help us to understand the role of this competition in the Portuguese musical and cultural scene of the late 1960s and 1970s, based on the study of the daily press. RTP Song Contest is the most long-life television contest in Portugal. For this reason, it is important to make a short historical overview of this period and the history of television in Portugal. At the same time, the analysis of statistical data of audiences enables us to understand the television phenomenon in the late 1960s.
\end{abstract}

Keywords: music and television, Festival RTP da Canção, Eurovision Song Contest, ethnomusicology

\section{Introduction}

The studies in music and television are recent in Portugal. For a few years now, the Portuguese ethnomusicologists have been developing research in this field. Some research has been presented (i.e. Lopes, 2012), and others are still under development (i.e. Pinto, 2014). At international level, studies on Eurovision Song Contest and the various national competitions have been growing and this academic field has been claiming through various publications. In Portugal, this subject is very recent in the academic scope and ethnomusicology is being developed the first systematic work (Lopes, 2013).

Sofia Isabel Fonseca Vieira Lopes, Ph.D., Instituto de Etnomusicologia, Centro de Estudos em Música e Dança, Faculdade de Ciências Sociais e Humanas, Universidade Nova de Lisboa. 
This article presents a reflection about the RTP Song Contest in late 1960s. I chose one of the most controversial examples of the contest's history that is still present in the Portuguese memory. I start by presenting some topics related to the historical context to better understand the importance of this episode. After some reflection on the television in Portugal and the role of music in this medium, I present the case of the Portuguese representation in ESC 1969. In that year, the expectations on political openness and renewal of Portuguese music, separating it from the aesthetic music National Radio, have been transposed into the song played by Simone de Oliveira. The expectations were not met and the boldness of Ary's lyric had no international echo which gave rise to a "national disappointment".

This research was presented at A Transnational Vision for Europe?: Performances, Politics and Places of the Eurovision Song Contest International Conference, at Malmö University, Sweden in May 2013 and results of the primary research work of my Ph.D. project.

\section{Portugal—A historical overview}

Between 1926 and 1974, for almost fifty years, Portugal went through a dictatorship. From 1932 on, António de Oliveira Salazar was the Prime Minister that influenced all venues of Portuguese administration. His office became known as Estado Novo (New State). During his thirty-six years of government, Salazar created a propaganda and a security organization that became essential for the establishment of the dictatorship. The absence of freedom of speech, of expression and association were effectively controlled by the censorship, the secret police, and Inspeç̧ão Geral de Espectáculos ${ }^{1}$ that examined all public demonstrations, including the media.

Like all authoritarian states, its image, inside and outside borders, was carefully planned. From 1933, SPN (National Propaganda Office), directed by Antonio Ferro, assumed the task of designing and implementing Salazar's cultural policy according to the regime's principles. Ferro had a clear perception of the role of culture as an instrument of power in service of a political regime, building a national rhetoric and promoting a good image of the nation. However, the State never sought to define an official aesthetic line for music, integrated in its political and ideological principles. As Côrte-Real explains,

the individual creativity and expression was inevitably conditioned by the image of the inspectors-militaries, lawyers and white collar workers in their majority_created for "acceptable” and "proper" expressive behavior. Not only the texts, but also the "attitudes", the "wardrobe" and the "gestures" were among the most frequent objects of censorship. (Côrte-Real, 2000, p. 32) ${ }^{2}$

Since its foundation in 1933, the National Broadcasting Station (Emissora Nacional) was considered one of most important and effective agents of ideological propaganda. In 1947, the Artists Training Center (Centro de Preparação de Artistas) was created within the National Radio with the intention of selecting and preparing new singers. Many of the singers who were trained at the Centro de Preparação de Artistas participated in the RTP Song Contest until 1974.

Its practice was based on the

\footnotetext{
1 "This institution, of crucial importance as a link between cultural policy and musical expression, was organized in 1929 and reorganized in 1962. (...) After being authorized, the performances were examined, as much as possible...” (Côrte-Real, 2000, p. 31). According to the author, for the state (Estado Novo) the concept of Espectáculo (show) was a synonym for expressive behavior liable to convey ideas and behaviors. Therefore, the need for their constant was checked by the state officials.

${ }^{2}$ Côrte-Real (2000): text originally in English; other texts translated by Sofia Vieira Lopes.
} 
transmission of an interpretative style that was associated with "light music"3. Here, musical education was based on the development of individual vocal expression, privileging good diction, voice adaptation to the microphone and studio and the relationship with the audience. (Moreira, Cidra, \& Castelo-Branco, 2010, p. 874)

Television would arrive in September 1956, twenty-four years after the regime's establishment, and under the "mistrust" of the Prime Minister. Censorship became a structural force and the basis of the whole political, technical, and discursive strategy in news magazines, configuring the instrumental device that TV was proving to be. As recent studies indicate, despite effective control of the press, radio, and television seem to have been somewhat apart this strict control (Cravinho, 2014; Pinto, 2014).

In September 1968, for health reasons, Salazar found himself unable to fulfill his political duties and the President of the Republic, Américo Tomás, appointed Marcello Caetano to assume the position of Prime Minister, a position he would occupy until 1974, the date of the 25th April Revolution (the "Carnation Revolution") that put an end to the dictatorship in Portugal. Marcello Caetano was considered a man with a cosmopolitan attitude and this change of attitude in the government brought the Portuguese people a hope of political openness. In fact, some political measures seem to aim the long desire and need to change; however, fundamental rights remained restricted. The truth is that between 1968 and 1974 Portugal witnessed an important opening to the outside ${ }^{4}$. The six years of Caetano's government were called by some people “Marcello Caetano's Spring” (Primavera Marcelista), but for others they were seen as the Autumn of the regime, that is, the beginning of its end.

\section{RTP—Radio Televisão Portuguesa-Portuguese National Television}

RTP (National Television) began its experimental broadcasts on September 4, 1956. As well as the National Radio and RTP was directed and controlled by the State. Six months after the first television broadcast in Portugal, in March 1957, RTP began regular broadcasts and definitely became part of Portuguese daily lives. The analysis of RTP programming schedules leads us to conclude that television, in the early years, followed models and procedures of the radio (Pinto, 2014). Until 1969, Portugal had only one television channel. The public channel RTP 2 premiered in 1969 and private television broadcasting began in the 90s.

TV sets had mandatory to be State licensed. In 1959, with an estimated thirty thousand television licenses, RTP joined European Broadcasting Union (EBU) ${ }^{5}$ and had its first audience analysis made. In Lisbon, 77\% of viewers watched TV in their homes, whereas $23 \%$ watched in public places; but the data reversed when analyzing the rest of the country. In Oporto region (the second largest urban center), $65 \%$ of viewers watched TV in public places; in the rest of the country, the overwhelming majority watched TV in public places (81\%). Watching television had a community character. People would gather together to watch television. So, RTP's

\footnotetext{
${ }^{3}$ In Portugal, and according to Encyclopedia of Music in Portugal in 20th Century, Light Music is a generic classification in the field of music production associated with mass media, music industry, and new forms of urban entertainment. It includes a diversity of musical styles and songs as the main genre, often called the light song. It is used since the end of the 19th Century. Its meaning is close to the Anglophone concept of popular music. It is a genre between art music and popular music associated to the lower social classes (Moreira, Cidra, \& Castelo-Branco, 2010, p.874).

${ }^{4}$ This doesn't mean that Portugal was completely closed to foreign influences. It is possible to see many external influences in music and television. For example, RTP broadcast several programs of foreign source production (in 1964, 4.6\% of programs were produced abroad, in 1968 this number rose to 30\%).

${ }^{5}$ According to EBU's website, “The European Broadcasting Union (EBU, UER in French) is the world's foremost alliance of public service media (PSM) with Members in 56 countries in Europe and overseas. Its mission is to safeguard the role of PSM and to promote its indispensable contribution to society. It is the point of reference for industry expertise and a centre for European media knowledge and innovation” (http://www3.ebu.ch/en/about, June 12, 2014).
} 
live broadcast shows became important national events.

In the first eight years, RTP shows were mostly live broadcasts and there was no effective technology for recording and subsequent transmission. All entertainment programs produced by RTP were performed and live broadcast. Only from 1964 on, videotape technology became available, and it allowed easy recording and later television broadcast. ${ }^{6}$ Because of the concerns related to unpredictability of public participation in live-broadcast or in the recording of programs, it was only in 1969 that live-programs could accommodate an audience. One of the first programs in the history of Portuguese television broadcast with public presence was the1969 RTP Song Contest, in February in São Luiz Theater. However, this program was designed, produced, and broadcast as a live show and not as musical television product.

In 1968, the RTP administration changed its outlines with the entrance of new administration chairman, Ramiro Valadão, directly appointed by the new Prime Minister. A newcomer from the United States, with a cosmopolitan spirit, Valadão had the important and difficult function of modernizing television, reflecting an apparent political liberalization advocated by Caetano and he also carried out an efficient job of controlling the TV content. Valadão had always in mind that television was the most important medium of political propaganda, especially at a time of increasing social protest of the late 1960's in Europe, when television began to be the center of the living rooms in the Portuguese homes.

\section{RTP Audiences and Schedule}

In the 1960's and 1970's, RTP had two types of musical programs: Art Music shows and Light Music shows. Within light music shows, the 1964 RTP Yearbook highlights the annual organization of RTP Song Contest, making evident the "attempt to enhance the quality of light music, not only in quantity but also on interpretive and production aspects" as well as the "contribution to the Portuguese music growth, encouraging the production of new compositions” (Anuário RTP, 1969). In the first editions, the singers, the composers, and the lyricists were already well-known to the public for their work on the National Radio. These factors may have contributed to the success of the competition. Therefore, according to RTP executives, light music programs "have always recieved great applause and approval” (Anuário RTP, 1969). We can see that they were more focused in what is accepted by the general public. Thus, it is a clear visible adequacy of the program's typology to a target audience. In the first audience study, we can see music programs ranked in second position of preferences, just after drama. Between 1961 and 1974, musical programs had an average of 12\% of RTP broadcast time and, within these, light music programs had a $5 \%$ of total broadcast time (see Figure 1).

Between 1958 and 1974, the broadcast time of RTP increased gradually to almost three thousand hours a year. The six years of Valadão's management showed a decrease in the time devoted to the broadcast of music programs. This decrease may be related to the substantial increase in time for sports, drama, and special programs (some dedicated to the military events of the Colonial War-1961-1974).

\footnotetext{
${ }^{6}$ The use of this technology since 1964 has enabled Portuguese participation in the Contest since sharing the recorded program with other members of the EBU was a precondition for participation in the Contest.
} 


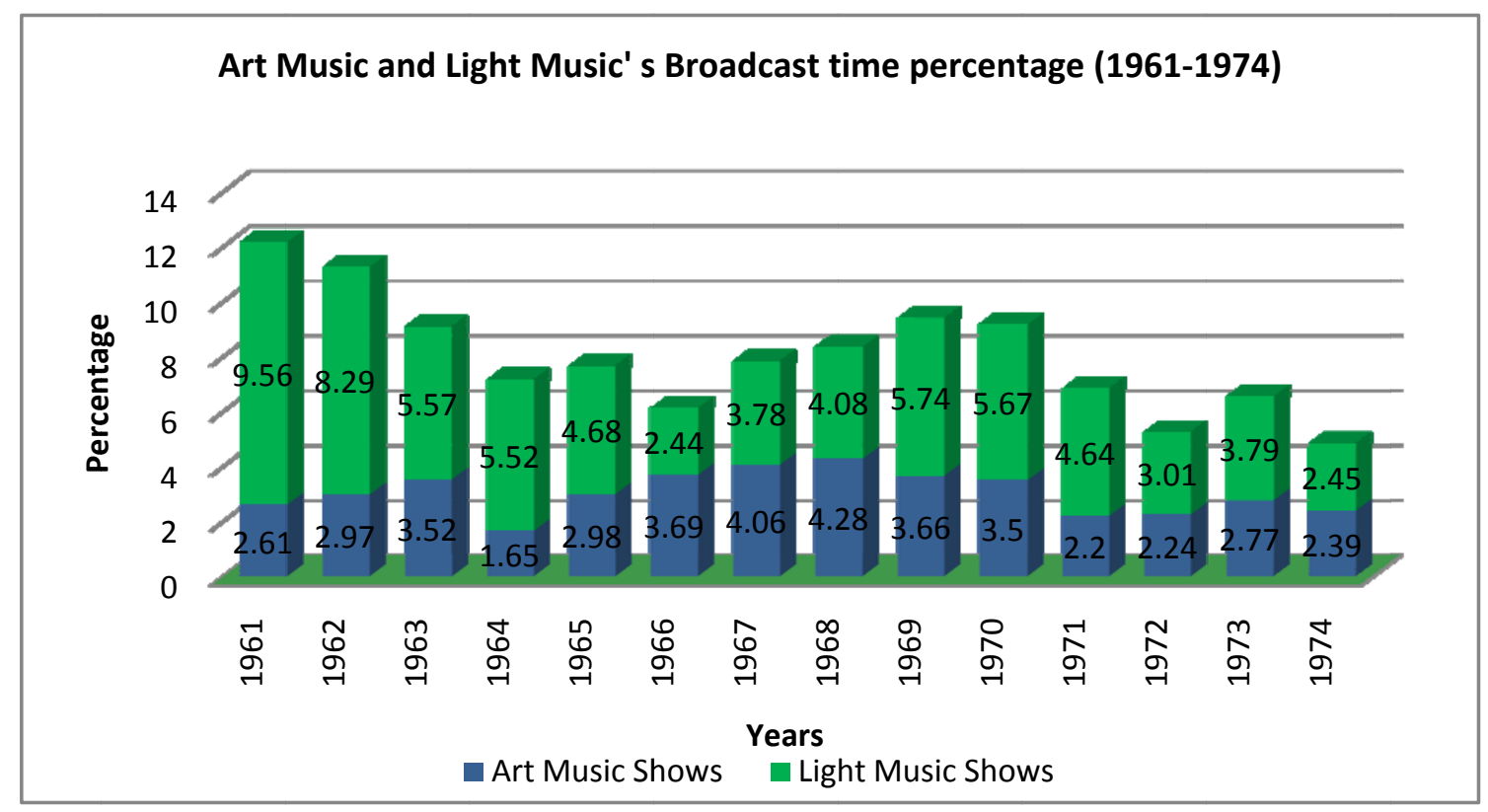

Figure 1. Art music and light music's broadcast time percentage.

\section{RTP Song Contest}

As stated in the Encyclopedia of Music in Portugal in the 20th Century,

During the last four decades of the twentieth century, [RTP Song Contest] contributed decisively to produce an unprecedented repertoire, particularly songs, and contributed to the emergence of new styles and the popularity of singers in the light and popular music (César, Tilly, \& Cidra, 2010, p. 501).

Premiered in 1964, RTP Song Contest, at the time so-called “TV Grand Prix of Portuguese Song”, not only answers the European Broadcasting Union request, but also is a kind of follow-up from an emerging practice in Portugal since the mid-1950s, where song festivals assumed an important role in the Portuguese music scene (Lopes, 2014).

The success of this competition reflected, on one hand, the novelty of RTP Song Contest in RTP programming schedule and the subsequent Portuguese representation in the Eurovision Contest; on the other hand, the participation of well-known singers on the radio who had trained at Centro de Preparação de Artistas (Artists Training Center) of National Radio. According to the Encyclopedia of Music in Portugal in the 20th Century, "RTP Song Contest, as annual event and television live-broadcast, caught the attention of a wide audience, making it the most important musical event in the country” (César, Tilly, \& Cidra, 2010, p. 502). For many years, RTP Song Contest was a "national event"; the country literally stopped at it. In the television competition, and like the current model in the light music scene of the time, the singer was accompanied by an orchestra (it was usually the National Radio Orchestra or other Radio station ensembles). On its first editions, not only the singers but many of the competing musicians and lyricists worked for the radio, Teatro de Revista ${ }^{7}$, and entertainment shows and they regularly participated in regional contests.

The contest involved three stages. On the first stage, the chosen songs were evaluated by a staff of experts

\footnotetext{
${ }^{7}$ Musical-theater genre that emerged in the 19th Century. It consists of several musical scenes marked by social and political criticism. The melody is very simple with a popular melody and rhythm and serves to camouflage the political messages.
} 
(jury) that analyzed the lyrics and music of each song. Later, during the orchestration, the composers selected the singers who would present their songs. On the final stage, during the TV show there was usually a featured jury panel representing the different parts of the country. This final stage and this voting model had been changing over the years according to the emerging policy of the State. This model continued until 1974. After that there has been a further democratization in the voting process and consequently a closer relationship with the audience.

In the late 1960s, though shyly, a new generation of musicians from Conjuntos Musicais ${ }^{8}$ and the new styles of international pop music began to be represented in RTP Song Contest. This new generation tried to follow not only the trends of international popular music but also to feature a style and attitude as a counterpoint to the performers of the Radio, introducing many contemporary elements. New singers claimed an opposite position of the so-called nacional-cançonetismo ${ }^{9}$. For example, in 1970 we saw important changes in RTP Song Contest performers when singers who became popular and well-known from another RTP program-Zip-Zip (RTP, 1969)—participated in the Contest. Zip-Zip promoted to the emergence of new singers and new lyricists who became known for their songs with political and social messages (Lopes, 2012). Later, RTP Song Contest gave them an international visibility.

\section{Desfolhada Portuguesa-The Revival of the Portuguese Light Music ${ }^{10}$}

In the course of my Master's research work about Zip-Zip, which I've mentioned above, I found an interesting issue about the Portuguese participation in the Eurovision Song Contest.

In the 1969 edition of RTP Song Contest, Simone de Oliveira, a widely known cançonetista ${ }^{11}$, who was seen at the time as a radio star, participated for the fourth time in this contest ${ }^{12}$. Simone de Oliveira sang a song entitled Desfolhada Portuguesa (Portuguese husking), with José Carlos Ary dos Santos’ lyrics, Nuno Nazareth Fernandes' melody, Joaquim Luís Gomes’ orchestration and conducted by Ferrer Trindade. This was the first edition of the Festival under Marcello Caetano's rule and the competing songs tried to echo the overall expected social and political change.

Nuno Nazareth Fernandes, the music composer, was not a newcomer in the Festival. In the previous year, the winning song had been written by Fernandes and sang by Eduardo Nascimento. The song highlighted not only an "aesthetic content opposite the 'Nacional cançonetismo', but also a strong ideological attitude in the lyrics that revealed the political and social situation at the time” (César, 2010, p. 474). His co-work with the lyricist José Carlos Ary dos Santos had started in 1968 and it was known, according to Encyclopedia of Music in Portugal, as the "renewal of the aesthetic and ideological content" (César, 2010, p. 473). In the following two years, this pair competed at the RTP Song Contest, winning the first prize again in 1971. Ary dos Santos

\footnotetext{
${ }^{8}$ Term used to describe a small musical group. In the 1960s, these groups played pop music according to the Anglo-Saxon model. ${ }^{9}$ Concept firsthand used by journalist João Paulo Guerra in an article published on July 19, 1969 in Diário de Lisboa. This derogatory term refers to the singers from the National Radio musical production whose songs were based on a patriotic vision and the rejection of foreign influences.

${ }^{10}$ Expression used in Joaquim Luís Gomes' interview—orchestrator of the 1969's winning song—published in New Antenna magazine (March 21, 1969).

11 A singer related to nacional-cançonetismo.

12 Simone participated in the First Portuguese Song Festival in 1958 (broadcast only by radio) and "thereafter, their media coverage was due largely to the participation in several festivals” (Silva, 2010, p. 934). She won the Festival da Canção Portuguesa in 1959 and 1960, the Festival da Figueira da Foz in 1962 and the RTP Song Contest in 1965 and 1969, and was awarded Queen of the Radio in 1964. In 1965, Simone represented Portugal in the Eurovision Song Contest with the song Winter Sun (Sol de Inverno).
} 
and Nuno Nazareth Fernandes and their team work were known for their contribution to the renewal of both the music and lyrics of the Portuguese light music. The lyrics of the winning songs brought Ary dos Santos an important public recognition. With his lyrics, Ary dos Santos had the opportunity to share his poetic imagery and political ideas, as the song was for him "a lyric wrapped in music (...) with the purpose of communicating with the general audience”"13 (Felix, 2010, p.1178). The use of metaphors, satire, irony and sometimes aggressive everyday language, and imagery gave Ary dos Santos's lyrics an important role in social intervention, which contributed to the renewal of the lyrical content of music. Besides the implicit ideological message, his lyrics have an outstanding part in the Portuguese literature. Ary dos Santos sometimes "was described by journalists and literary critics as a pamphleteer poet-which comes from his political engagement and the fact that many of his lyrics have become a political reference” (Félix, 2010, p. 1179).

Running through March21, 1969, Nova Antena magazine, one of the highlighted issues was the interview with Maestro Joaquim Luís Gomes. Maestro, called here as one of the "biggest names engaged in the rebirth of Portuguese light music” (Gaspar, 1969, p. 24), highlights the role of orchestrators for the continuity of festivals songs like RTP Song Contest. In Maestro’s opinion, 1969 RTP Song Contest had introduced a higher literary level; however, he believed that music did not follow this trend, as a result of an excessive amateurism. Maestro describes Desfolhada as: "a symbiosis of folklore-fado, fado incorporated into folklore, emphasizing the local colors, which makes Desfolhadaa unique song” (Gaspar, 1969, p. 24), pointing out the inclusion of a Portuguese guitar for the first time present in Eurovision Song Contest. ${ }^{14}$ In Gomes’ opinion,

this year there is more truth in our representation. Things are much more rooted in our musical language. (...) If something is expected on an international festival, I think it is the local color, the representativeness of each of the songs, their ethnic features. (Gaspar, 1969, p. 24)

On the Eurovision Song Contest proceeding days, the Portuguese press highlighted the participation of Simone de Oliveira. On a trip to Madrid, Diário de Lisboa, a Portuguese daily newspaper reported the presence of hundreds of fans at the train station that "surrounded the cançonetista, pushed her against the train carriage, asked autographs, gave kisses, said goodbye, sang the first bars of Desfolhada and shouted "Simone! Simone! Victory!”, possessed by an enthusiasm which became difficult to report in detail” (Diário de Lisboa, March 25, 1969).

For Simone, the country had assumed victory. In the following days, there were several reports claiming that the Portuguese song was one of the best, mainly due to the quality of the lyrics and the performer's voice. For the Portuguese journalists, Simone brought a "new soul" and a "smile of hope". It is interesting to read what Diário de Lisboa published on March 29:

A couple of hours from the epilogue, the festival remains a mystery. If the jury faces the problem under political aspects, we have Germany or Yugoslavia at the top positions. If they watch the issue in terms of business, it is certain that only England or Spain can win. If we size up the artistic value, Portugal, Switzerland, Holland or Italy are the favourites. But if the "great ruler" fancies to "pop music" or overwhelming feelings, it may be time for Belgium or Monaco (Faustino, 1969, p. 1)

On the same day, César Faustino a journalist from Diário de Lisboa predicted:

\footnotetext{
${ }^{13}$ Citation from Século Ilustrado, March 1, 1969

${ }^{14}$ In the Portuguese contest, the Portuguese guitar melodic line was played by a female integrated in a chorus of three female voices.
} 
Beware optimists either I am mistaken—hopefully—or we'll see Portugal again in one of the last positions in spite of the song credits or the performer value. Without doubt, the Portuguese song is a very good song. Final voting is a sham every year. A grotesque comedy of pre-fabricated scores and falsified ratings, combining neighbourhood games and linguistic groups solidarity or morbid political retaliations. (Faustino, 1969, p. 8)

The winners were France, Spain, United Kingdom, and the Netherlands. In Madrid, the Portuguese song was ranked in the fifteenth place with four points (the last but one). The press wrote about the Portuguese disillusion, reporting the warming welcome back to Simone de Oliveira at her arrival. For Maestro Nóbrega e Sousa, interviewed by Nova Antena on May 2, 1969,

The result of the vote of the Eurovision Song Contest was unfair. Our song deserved a better score. This I considered a weak festival. Singers did not satisfy me greatly; and our Desfolhada wasn't fully appreciated by the European jury. I repeat, that it is a good song, but it seems to me that we have overstated, perhaps, when proclaiming that this song marked a new level in the evolution of the Portuguese light music. (D’Almeida, 1969, pp. 20-21)

For Mário Castrim, one of the leading television critics of the time, Simone seemed to "mourn their sorrow", with a dramatic, ultra-romantic and a little careless song, "barely thought for those who wish to win European festivals". According to Castrim, "universal refrains and lots of beautiful legs is what it is necessary" (Castrim, 1969, p.10), since the winning songs reflected the weakness of the Western European music. In spite of criticizing the importance of the business word in the choice of songs, Castrim did not doubt to say that Simone de Oliveira sang badly a poorly orchestrated song.

To the journalists, the song by Simone de Oliveira reflected a shifting paradigm in the songs that increasingly tried to move away from the rhetoric of the New State. The comparison between the carnal love expressed in the sentence "who makes a baby makes it with pleasure" and love by the motherland made the audience speak about Simone and Desfolhada. In an interview, Simone declares: "They told me everything. Insulted me in restaurants at lunchtime, at dinner time, just do not hit me by chance”15 (Costa, 2013). In Castrim's opinion, to bet on a "Slavic song" was one of the causes for the Portuguese defeat and he makes a point that "both in songs as well as in history, you never win when you bet on the old recipe" (Castrim, 1969, p.10). The author criticized the orchestration and the introduction of the Portuguese guitar. Due to the political engagement of its authors rather than a new message of the song or the different style of musical composition, Desfolhada Portuguesa was the greatest success of Simone de Oliveira career and it is still one of the most famous songs of the RTP Song Contest. A few months after her defeat, between 1969 and 1972, Simone interrupted her career due to vocal tract problems.

After the Portuguese defeat in 1969, RTP decided not to participate in next year's edition. In a moment of longing desire for a change such as Portugal was going through, Desfolhada was also a synonym for change and hope but the bad result discouraged the Portuguese people. In the media, there were several references to the unfair Portuguese result on Eurovision. Political relationships between countries are often presented as justification for the Portuguese defeat. Once again, Portugal felt "proudly alone” (expression used by Salazar) at a time when the international community was increasingly challenging the Portuguese colonial policy.

\section{Conclusion}

For many years, the RTP Song Contest was able to gather Portuguese people around the television, and it

15 Diário de Notícias online: http://www.dn.pt/revistas/ntv/interior.aspx?content_id=3147394 (September 1, 2014). 
was a subject of conversation for audiences of different generations, what stands out the status and importance of television in the Portuguese community. It is important to mention Spigel's statement (1992) when he refers to the difference between films and television, but that is easily transposed to this context:

Whereas film allowed spectators imaginatively to project themselves into a scene, television would give people the sense of being on the scene of presentation-it would simulate the entire experience of being at the theatre. (Spigel, 1992, pp. 138-9)

This is always an audio-visual experience to the audience. And this is an emotional experience, too. Audience is exposed to the competition and the expressive behavior. This involvement is only possible via television as an interactive musical experience. It creates empathy between the audience and the performers in a way that I consider more effective compared to the radio broadcast.

Moreover, beyond the jury' scrutiny, there is a parallel audience' scrutiny that takes place in two distinct contexts: in private context, when watching the program at home; in public context, since it was common practice for viewers to watch TV in public places. This scrutiny is assumed as a major factor for the success of this contest. Thus, the public is no longer a passive viewer, but is a part of the action on an interactive relationship.

RTP Song Contest and the Eurovision Song Contest were thus fundamental to music production in Portugal in the 1960s and 1970s. In fifty years, the RTP Song Contest promoted the production of thousands of original songs, enabled the widespread of approximately 450 songs, encouraged and cemented the popularity of more than four hundred singers.

From the transmission of regional competitions and, after 1964, with the regular organization of FRTPC, public television cherished the events that were considered fundamental for the development of Portuguese music (emic concept used by journalists, composers and performers) as a way to curb the dominance of foreign music in the Portuguese music scene.

The 1969 edition had a most special impact, since it was believed that Simone de Oliveira's song represented the changing political attitude, the "Spring” of Prime-Minister Marcelo Caetano.

Cádima (1996) conveys the idea that due to the power of the image, TV, and specially RTP Song Contest fulfils, in a way a very particular function: being phatic, shaping people’s identity, being connected.

\section{References}

Anuário RTP (RTP Yearbook). (1969). Lisboa: RTP.

Cádima, F. R. (1996). Salazar, Caetano e a Televisão Portuguesa (Salazar, Caetano and the Portuguese television). Lisboa: Editorial Presença.

Castrim, M. (1969, March 30). O Festival terminou quadrúpede (The ESC ends quadruped). Diário de Lisboa, 10

César, A. J. (2010b). Nuno Nazareth Fernandes. In S. Castelo-Branco (Ed.), Enciclopédia da Música em Portugal no Século XX (Encyclopedia of Music in 20th Century Portugal). Lisboa: Círculo de Leitores/Temas e Debates.

César, A. J., Tilly, A., \& Cidra, R. (2010a). Festival RTP da Canção (RTP Song Contest). In S. Castelo-Branco (Ed.), Enciclopédia da Música em Portugal no Século XX (Encyclopedia of Music in 20th Century Portugal). Lisboa: Círculo de Leitores/Temas e Debates.

Côrte-Real, M. S. J (2000). Cultural policy and musical expression in Lisbon in the transition from dictatorship to democracy (1960's to 1980's) (Ph. D. dissertation, Columbia University).

Costa, R. (2013, April 4). Simone de Oliveira: “Tenho uma solidão minha, que não é explicável por palavras” (Simone de Oliveira: "I have a myloneliness, which is not explained by words”. Diário de Notíciasonline. Retrieved 2014, September 1 from http://www.dn.pt/revistas/ntv/interior.aspx?content_id=3147394 
Cravinho, P. (2014, February). “Vinte Minutos de Jazz...” Os primeiros programas de jazz na televisão em Portugal (1958-1963) (“Twenty minutes of Jazz...” The first jazz programs on Portuguese television (1958-1963)) (Paper presented at the Conference Musicologia Criativa, Porto).

D’Almeida, C. (1969, Mai 2). A música portuguesa em discussão: Há ainda muito a fazer—opinião de Nóbrega e Sousa (The Portuguese music under discussion: There is still much to do-Opinion of Nobrega e Sousa). Nova Antena, 20-21.

Eurovision Broadcast Union. (2014). Retrieved 2014, June 12 from http://www3.ebu.ch/en/about

Félix, P. (2010). José Carlos Ary dos Santos. In S. Castelo-Branco (Ed.), Enciclopédia da Música em Portugal no Século XX (Encyclopedia of Music in 20th Century Portugal). Lisboa: Círculo de Leitores/Temas e Debates.

Fautino, C. (1969, March 29). Estanoite a Europa sentada em frente ao pequeno ecrã (Tonight Europe will be sitting in front of the small screen). Diário de Lisboa, 1, 8-9.

Gaspar, F. (1969, March 21). Joaquim Luís Gomes: uma guitarra para a “desfolhada” (Joaquim Luís Gomes: a guitar for “leafless”). Nova Antena, 24.

Lopes, S. V. (2012). Duas horas vivas numa TV morta: Zip-Zip, Rádio e Televisão no preâmbulo da democracia em Portugal ("Two alive hourson a dead TV”: Zip-Zip, MusicandTelevision in thedemocracy’spreamble in Portugal) (Master thesis, FCSH-UNL).

Lopes, S. V. (2013). “Em play back”: O Festival RTP da Cançãonaprodução e mediação da músicaem Portugal (1964-2012) ("Playback": The RTP Song Contest in the production and mediation of music in Portugal (1964-2012)) (Ph.D. project at FCSH-UNL).

Lopes, S. V. (2014). O concurso enquanto espectáculo musical-Reflexões acerca dos antecedentes do Festival RTP da Canção (The contest as musical show-Reflections about the RTP Song Contest ancestors) (Paper presented at the Conference Musicologia Criativa, Porto)

Moreira, P., Cidra, R., \& Castelo-Branco, S. (2010). Música Ligeira (Light Music). In S. Castelo-Branco (Ed.), Enciclopédia da Música em Portugal no Século XX (Encyclopedia of Music in 20th Century Portugal). Lisboa: Círculo de Leitores/Temas e Debates.

Pinto, J. R. (2014, February). Da Rádio para a Televisão: Modelos e processos de produção musical nos primórdios da televisão em Portugal (From Radio to Television: Models and music production processes in the early days of television in Portugal) (Paper presented at the Conference Musicologia Criativa, Porto).

Silva, J. (2010). Simone de Oliveira. In S. Castelo-Branco (Ed.), Enciclopédia da Música em Portugal no Século XX (Encyclopedia of Music in 20th Century Portugal). Lisboa: Círculo de Leitores/Temas e Debates.

Spigel, L. (1992). Make room for TV: Television and the family ideal in postwar America. Chicago: University of Chicago Press. Simone a caminho de Madrid (Simone goes to Madrid). (1969, March 25). Diário de Lisboa, 1-2. 